\title{
A Scale Development for 21st Century Skills of Primary School Students: A Validity and Reliability Study ${ }^{1}$
}

\section{Ş. Dilek Belet Boyacı}

Assoc. Prof., Anadolu University, Faculty of Education, Primary Education Department, Eskişehir, Turkey, sdbelet@gmail.com

\section{Nurhan Atalay}

Dr., Eskişehir Osmangazi University, Faculty of Education, Primary Education Department, Eskişehir, Turkey,nurratalay@gmail.com

The objective of the present study is to develop a measurement tool to assess 21 st Century learning and innovation skills of primary school students. Study data was collected from 632 fourth grade students in five different primary schools during 2014 - 2015 academic year and data obtained from 609 fourth grade students were utilized in the study. The scale was developed in six stages. These were; establishing the scale items, consultation of experts, pretest stage, determination of structural validity, reliability assessment, and finalization of the scale, respectively. Cronbach alpha reliability coefficient for the whole scale, which consisted of three factors, was calculated as 0.95. 0.89. As a result of the current study, a Likert-type 21st Century learning and innovation skills scale with 39 items was developed. 20 items of the scale were related to creativity and innovation skills, 12 were related to critical thinking and problem solving skills, and 7 were related to cooperation and communication skills.

Keywords: primary school, $21^{\text {st }}$ century, learning and innovation skills, scale, validity and reliability

\section{INTRODUCTION}

In today's society, which was christened as the information society where information is produced and spread to the large masses rapidly, information is the most significant phenomenon and individuals are also expected to reach that knowledge. Along with the technological developments, scientific innovations, increasing globalization, changing labor demands, economic pressures and rapid changes in competition in today's society,

\footnotetext{
${ }^{1}$ This paper is based on a PhD study titled "Applying Slowmation in Science Lesson to Improve Students' Learning and Innovation Skills". This thesis study was supported by Anadolu University. Project Number: 1407E358
} 
the skills required in the students to contribute to the society and increase their readiness for society were redefined (Levy and Murnane, 2005; Stewart, 2010; Wilmarth, 2010). In information society, the individuals are expected to adjust to the complex society, select knowledge within the information mass, analyze this knowledge to utilize it to solve problems of daily life and to transform it into products. Thus, individual should possess high level skills such as analytical thinking, inter-personal skills and organization of knowledge (Velez, 2012). The needs of individuals in the 21 st Century to work, for citizenship and to realize oneself are quite different from their possessions in the 20th Century. 21st Century skills are different from that of the 20th Century primarily based on the emergence of advanced information and communication technologies (Dede, 2009; Shute and Becker, 2010).

Throughout history, critical thinking and problem solving skills were the main components of human development such as exploration of land and the seas, discovery of vaccines, agricultural developments and in many other fields. However, since skills such as information literacy and global awareness could be found in different societies, these are no longer considered as new skills. Plato expressed these concepts as four different levels of the mind back in mid Third Century (Rotherham and Willingham, 2009). Conceptual framework of these skills, named as 21 st Century skills, were considered in different dimensions by P21 (Partnership for 21st Century skills), NRC, Metiri Group and NCREL (North Central Regional Education Laboratory) (2003), American Association of Colleges and Universities (2007), and OECD (2005). National organizations including P21 and NRC investigated the interactions between 21st Century skills and education and their instruction in core disciplines to identify and define 21st Century skills (NRC, 2006; P21, 2009). Since it is an accepted fact that the developments in information and communication technologies had a profound effect on 21st Century skills, student technology standards included in the programs based on ISTE NETS*S (International Society for Technology Education, 2007) data were reviewed and organized (Dede, 2009). Educational demands and skills of the new century require new ways in thinking, learning and teaching (Keengwe, Onchwari and Wachira, 2008; Razzouk and Oroszlan, 2011). In today's societies, there is a need for individuals, who could research and structure the information, with critical thinking skills, could resolve the problems with own knowledge and experience, are creative, open to innovations, and at the same time, with effective communication and cooperation abilities within a group. P21 (2009) called these skills, which the individuals should possess, 21st Century skills and classified these as "Learning and Innovation Skills," "Life and Career Skills," and "Information Media and Technology Skills." According to Prensky (2001) and Rotherdam and Willingham (2010), 21st Century skills are not a different set of skills. Every individual is expected to have creative thinking and problem solving skills that are required for active participation of the individual in the society and the workplace. For students' achievements in educational life, they should experience these skills at a very early age (Louis, 2012).

Thus, the renewed primary school instruction programs included these skills as well. Primary schools have a significant function in formation of the future educational steps and due to the fact that the information and skills obtained in this level affect the future 
training experiences. According to Gültekin (2007), primary school, which is the initial step of primary education, sustains the society by transferring the cultural background and values of the society to the future generations; on the other hand, by providing basic information and skills for the individuals, it increases the social and cultural level of the society. In other words, the objective of the primary school is to increase the quality of life of individuals and the society by spreading education among the masses. The skills of "creativity and innovation," "critical thinking and problem solving," and "communication and cooperation" under learning and innovation skills coincide with the skills included in primary school instruction programs. It is significant to provide lifelong learning and 21st Century skills for the students from the primary school on (Shin and Lee, 2008). Along with the technological developments and changes in the field of education and the innovations in the content of instructional programs and in learning-teaching process, it became necessary to determine the level of efficacy of the students in these skills. Several measurement tools were developed to measure these skills of students in the literature.

Torrance (1966) developed a scale influenced by Guilford's Cognitive Learning Ability test, one of the Verbal A and Verbal B forms, designed to measure creative thinking skill. This scale is a paper-and-pencil test that measures individual creativity. This test, one of the most known and frequently applied tests based on divergent thinking, was restructured several times until it took the form used today (Torrance, 1990). "How Creative Are You?" creativity scales developed by Raudsepp (1977) and Whetton and Cameron (2002) were translated into Turkish and used in several studies.

"California Critical Thinking Tendency Scale" developed by Facione and Giancarlo (1992), a test developed by Ennis-Weir (1991) to measure the logical dimension of critical thinking, Özdemir's (2005) "Critical Thinking Skill Scale," another "Critical Thinking Skill Scale" developed by Demir (2006), and Watson-Glaser's (1980) "Critical Reasoning Power Scale" were used in several studies.

"Problem Solving Inventory" developed by Heppner and Peterson (1982) and other problem solving inventories developed by Taylan (1990), Ge (2001), Yaman (2003), Çam and Tümkaya (2008) to measure problem solving skill perceptions of high school students, pre-service teachers and adults and were used in several studies. Serin, BulutSerin and Saygili (2010) developed an inventory consisting of three factors and 24 items; "confidence" (12 items), "self-control" (7 items) and "avoidance" (5 items), to measure the self-perception of primary school students on their problem solving skills.

Kang et al. (2010) developed a 21st Century skills scale for high school and middle school students that included cognitive, affective and sociocultural sub-dimensions. Kang et al. (2012) later adapted this scale for the primary school level students. Furthermore, Deborah (2012) developed a scale for teachers for determination of utilization of 21 st Century skills at schools, which included "education and instruction," "professional community" and "school culture" sub-dimensions.

There are limited number of original scales and Turkish adaptations that measure all of these skills; however there are scales that measure the skills separately. Most of the 
scales were developed for use with adolescents and adults (Çam and Tümkaya, 2008; Deborah, 2012; Kang et al., 2010; Özdemir, 2005). As a result of innovations in educational content and learning-teaching process, a need for measurement tools has arisen to determine the levels of these skills that the students have. It was observed that the scales developed to measure all skills in middle school, high school and college levels did not include psychometric features required to measure skills and behavior of primary school students. The lack of a measurement tool designed for primary school students was the starting point of the present study. To fill this gap, it was considered that the development of "21st Century Learning and Innovation Skills" scale would contribute to the field and could help determine whether the individuals possess these skills at an early age, and could serve as a resource for experts and educators, who would conduct research in this field. Thus, the present study aimed to develop "21st Century Learning and Innovation Skills" scale, which would determine "Creativity and Innovation," "Critical Thinking and Problem Solving," and "Cooperation and Communication" skills of primary school students. In this framework, the current study scrutinized the validity and reliability of the scale that would be developed to determine "21st Century Learning and Innovation Skills" of fourth grade primary school students.

\section{METHOD}

The present research is a scale development study. The developmental stages for the "21st Century Learning and Innovation Skills" scale and the characteristics of the study group are detailed below.

\section{Study Group}

The selection of the sample in scale development studies is still a matter of debate. In the literature, while Comrey and Lee (1992) considered a sample size of 100 participants as insufficient, 200 participants as average, 300 participants as good, 500 participants as very good, and 1000 or more participants as perfect, Field (2009) stated that at least 300 participants are required to conduct factor analysis. Thus, the universe of the present study included fourth grade students that attended the primary schools in Adiyaman province of Turkey during 2014-2015 academic year. Sample of the study consisted of 632 students attending the fourth grade in five primary schools located in Adiyaman city center, determined with random sampling from different socio-economic areas. The forms completed by 23 students out of 632 were excluded from the study due to reasons such as missing answers, selecting more than one multiple choice answers. The responses excluded by students were not included in the study and responses by the remaining 609 students were analyzed.

\section{Scale Development Process}

The "21st Century Learning and Innovation Skills" scale was developed in six stages of establishing the items of the scale, consultation of experts, pretest stage, determination of structural validity, reliability assessment, and finalization of the scale, respectively.

Establishing the Items of the Scale

The objective of the study is to determine the degree that fourth grade primary school students had 21st Century learning and innovation skills. A multidimensional approach was followed in the study and a literature review was conducted by considering all 
phases of 21 st Century learning and innovation dimension. Preliminary items were identified by taking into account the scale items that existed in the reviewed studies in the literature.

\section{Expert Opinion}

Draft scale consisted of 60 items. Opinions of five experts in the field were consulted on the draft scale. The experts scrutinized the items based on their suitability for the dimension, comprehensibility of the expressions, whether the items concerning the skills under each dimension reflected all the characteristics of the related skill, and whether these were suitable for fourth grade students. As a result of expert assessments, four statements that were not suitable for the level of students and comprehensibility of the statements were excluded from the scale, while five statements that did not reflect the related skills completely were edited.

\section{Pre-Test Stage}

To determine the answering duration and comprehensibility of the scale, the 56-item scale was applied to 30 fourth grade primary school students in the pre-test stage. As a result, two statements that were not understood clearly by the students were edited. 56item draft scale was thus finalized. During the following phase, the scale was applied to the students and scores obtained from the scale were analyzed.

\section{Determination of Structural Validity}

Exploratory factor analysis was conducted on obtained data to determine the structural validity of the scale. Exploratory factor analysis (EFA) is an analysis technique that enables researchers to identify and group the items that measure the same structure or quality among the items determined previously and explains the measurement with these small number of superstructures (factors) (Büyüköztürk, 2007). Exploratory factor analysis was conducted initially, followed by the confirmatory factor analysis to establish the structural validity of the scale. Confirmatory factor analysis (CFA) is a statistical method used to determine whether the variable groups within predetermined factors would sufficiently be represented by these factors (Büyüköztürk, 2007; Tabachnick and Fidell, 2007). In this process, primarily Kaiser-Meyer-Olkin (KMO) and Bartlett Sphericity tests results were examined, followed by the common factor variance values for the items, eigenvalue line graph, principal components analysis results, and "verimax" rotation technique results, conducted to obtain interpretable variables. As a result of the interpretation of the above-mentioned data, the scale was finalized.

\section{Assessment of Reliability}

One of the main problems that scales used in educational research face is the issue of reliability. In this stage, item-total test score correlations between the items and Cronbach alpha reliability coefficient value was calculated and analyzed to test the reliability of the scale. Cronbach alpha reliability coefficient value is a measure of internal consistency between the scale test scores and values of 0.70 or higher are 
accepted as sufficient for test reliability. Item-total test score correlation is used to explain the relationship between the item score and test items total score. A high and positive item-total test score correlation demonstrates the internal consistency of the scale (Büyüköztürk, 2007).

\section{Finalization of the Scale}

Certain items were omitted from the scale as a result of the processes explained in the above stages and the scale was finalized.

\section{FINDINGS}

Findings are grouped under three titles for a better systematic presentation:

1. Assessment of data for factor analysis suitability

2. Analysis of the structural validity of the scale

3. Analysis of the reliability of the scale

\section{Assessment of data for factor analysis suitability}

Factor analysis is a multivariate statistical method that aims to discover smaller number of conceptually significant new variables (factors, dimensions) by aggregating greater number of variables (Büyüköztürk, 2007). Initially, the suitability of the date for EFA was controlled. For this purpose, missing data in the measurement tools, reverse items, normality of the dataset, relationships between the variables, sample size, and sample suitability were controlled using KMO and Bartlett sphericity tests (Büyüköztürk, 2007; Field, 2009; Tabachnick and Fidell, 2007). Items 19, 23, 26, 28, 41, 42, 45, 53, which contained negative statements were reversed. Results demonstrated that Bartlett test was significant $(\mathrm{p}<0.05)$ and $\mathrm{KMO}$ value was greater than $0.50(\mathrm{KMO}=.943)$. Related literature would show that a KMO value of 0.60 is considered as moderate; 0.70 as good; 0.80 as very good; and 0.90 as perfect (Sharma 1996, Bryman \& Cramer, 1999; Şeker, Deniz and Görgen, 2004). Table 1 demonstrates Bartlett test and KMO results.

Table 1: Kaiser-Mayer-Olkin (KMO) sample measurements and Bartlett's test results

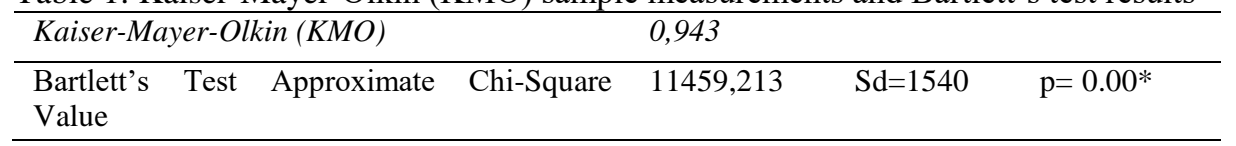

Data presented in Table 1 demonstrates that the obtained data were suitable for exploratory factor analysis as the KMO coefficient of 0.943 reflected that sample size was perfect and Bartlett's test results reflected a correlation between the items of the scale.

\section{Analysis of the structural validity of the scale}

EFA was conducted with the data obtained from the first 304 students, and CFA was conducted using the dataset for the second 305 students in the study. According to Worthington and Whittaker (2006), EFA and DFA should be conducted with different samples. Thus, 609 students were randomly divided into two groups and EFA analysis was conducted on one group, whereas CFA analysis was conducted on the other. 


\section{Findings for the Exploratory Factor Analysis (EFA)}

In EFA, the qualification of the sample was analyzed using Kaiser-Meyer-Olkin (KMO) value and the suitability of the data for factor analysis was analyzed using Bartlett's Sphericity value. It was determined that KMO coefficient for the data was .943 and Bartlett's Sphericity test $\chi 2$ value was $11,459.213$ and both values were significant $(p<$ .05). Factor analysis for the scale was conducted with Principal Components Analysis technique. To support the results and to make an accurate decision on the number of factors in the scale, Scree graph, which is based on the factor eigenvalues, was also analyzed (Büyüköztürk, 2007). As a result of the analyses and based on the discontinuities in the graph, a three-factor structure was determined for the scale. The break point observed in the Scree plot, which is related to the number of factors, also indicated a three-factor structure. As a result of the initial EFA analysis, 56 items were grouped under eight factors to explain $62.708 \%$ of the total variance. The minimum value in determination of the factor loads of the items was set as .30 (Pallant, 2001). At this point, the items that did not have a difference of at least .10 between the factor load values that the item received in more than factors (i.e. overlapping items) were excluded from the scale starting from the least necessary items. Pallant (2001) also indicated in the common variance (communalities) table that the values below .30 were not compatible with other items in the same factor. Thus, common variance table was controlled when each item was excluded; however a value below .30 was not encountered in any phase. The scale was finally formed with three factors including 39 items. In the next step, to group the items that demonstrated high level of relationship with each other, it was decided to implement Varimax Orthogonal Rotation technique (Büyüköztürk, 2007; Kalayc1, 2005). Item analysis of the scale supported the findings that the scale was three-dimensional as a result of the Varimaz Orthogonal Rotation as well. It was identified that the total variance that the scale explained with the items grouped under three factors was $61.302 \%$. Concurrently, Cronbach reliability coefficient for the scale was determined as $\alpha=.955$. Rotated factor loads for the scale, the variances explained by different factors and reliability information are presented in Table 2 .

Table 2: Factor load values and common factor variance for the 21st Century learning and innovation skills scale

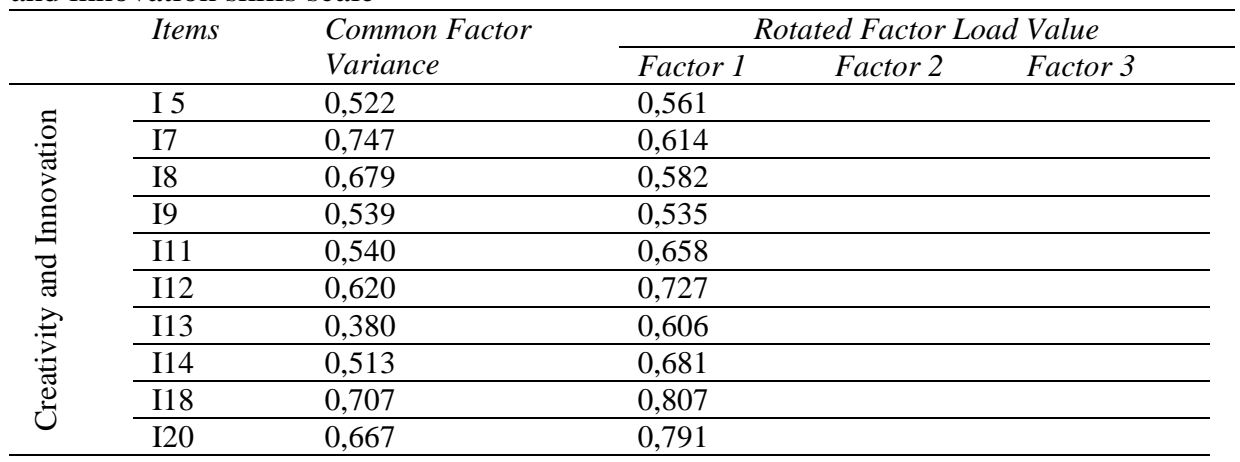




\begin{tabular}{|c|c|c|c|c|c|}
\hline & I36 & 0,530 & 0,692 & & \\
\hline & $\mathrm{I} 38$ & 0,564 & 0,742 & & \\
\hline & I39 & 0,638 & 0,771 & & \\
\hline & $\mathrm{I} 40$ & 0,687 & 0,807 & & \\
\hline & I43 & 0,609 & 0,754 & & \\
\hline & I44 & 0,658 & 0,794 & & \\
\hline & $\mathrm{I} 45$ & 0,536 & 0,681 & & \\
\hline & I46 & 0,513 & 0,691 & & \\
\hline & I47 & 0,671 & 0,793 & & \\
\hline \multirow{12}{*}{ 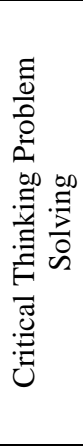 } & $\mathrm{I} 3$ & 0,452 & & 0,501 & \\
\hline & I4 & 0,635 & & 0,612 & \\
\hline & $\mathrm{I} 21$ & 0,762 & & 0,871 & \\
\hline & $\mathrm{I} 23$ & 0,431 & & 0,653 & \\
\hline & $\mathrm{I} 25$ & 0,712 & & 0,834 & \\
\hline & I27 & 0,630 & & 0,783 & \\
\hline & $\mathrm{I} 29$ & 0,599 & & 0,754 & \\
\hline & $\mathrm{I} 30$ & 0,806 & & 0,892 & \\
\hline & I31 & 0,456 & & 0,666 & \\
\hline & $\mathrm{I} 32$ & 0,690 & & 0,828 & \\
\hline & I33 & 0,750 & & 0,860 & \\
\hline & I34 & 0,755 & & 0,861 & \\
\hline \multirow{9}{*}{ 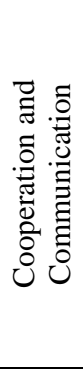 } & I48 & 0,669 & & & 0,773 \\
\hline & I49 & 0,704 & & & 0,760 \\
\hline & I50 & 0,692 & & & 0,801 \\
\hline & I51 & 0,653 & & & 0,774 \\
\hline & I52 & 0,619 & & & 0,745 \\
\hline & I53 & 0,381 & & & 0,600 \\
\hline & I54 & 0,650 & & & 0,786 \\
\hline & \multicolumn{2}{|c|}{ Total variance explained $\% 61,302$} & $\% 27,730$ & $\% 21,819$ & $\% 11,754$ \\
\hline & \multicolumn{2}{|c|}{ Cronbach alpha $\alpha=.955$} & $\alpha=.958$ & $\alpha=, 943$ & $\alpha=.896$ \\
\hline
\end{tabular}

For an item to be placed under a factor, it should have a factor load of at least .30 (Pallant, 2001). As could be observed in Table 2, the first factor included 20 items with factor loads that varied between .53 and .80; the second factor included 12 items with factor loads that varied between .50 and .89 ; and the third factor included 7 items with factor loads that varied between .60 and .80 . It was observed that all factors explained $61.30 \%$ of the total variance. The first factor explained $27.73 \%$ of the total variance and named as "creativity and innovation" with the guidance of the previous studies in the literature. The second factor explained $21.81 \%$ of the total variance and named as "critical thinking and problem solving." The third factor explained $11.75 \%$ of the total variance and named as "cooperation and communication." Analysis results demonstrated that all items were under the planned dimension with the exception of three items. Two items (I38 and I44) were considered under critical thinking and problem solving dimension during the planning phase, however EFA results determined that these were under creativity and innovation dimension. One item (I9) was considered under cooperation and communication dimension during the planning phase, however EFA

International Journal of Instruction, January $2016 \bullet$ Vol.9, No.1 
results determined that this item was under critical thinking and problem solving dimension. Post-analysis expert opinion agreed that these 3 items could be placed under the dimensions determined by EFA results.

\section{Findings for Confirmatory Factor Analysis (CFA)}

CFA was conducted to test whether the data collected from the second study group would confirm the scale structure with 39 items and three factors obtained as a result of EFA. Goodness of fit indices obtained from the confirmatory factor analysis conducted on the three-factor structure are given below before application of any modifications on

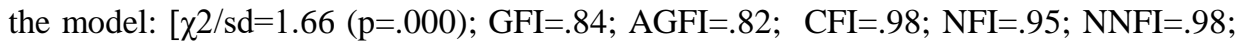
$\mathrm{IFI}=.98 ; \mathrm{RMSEA}=.047 ; \mathrm{SRMR}=.051 ; \mathrm{PNFI}=.89$ ve $\mathrm{PGFI}=.75]$. Connections between $\mathrm{I} 3$ and I21, and I4 and I23 items, proposed by the modification indices that were obtained as a result of the analysis were analyzed. As the theoretical analysis concluded that these items measured similar conditions and there could be a hidden relationship among them, modification suggestion was considered. Fit indices for the modes obtained as a result of the modification are displayed in Table 5. Perfect and acceptable fit criteria observed in Table 5 demonstrated that the goodness of fit level of the threefactor model obtained as a result of CFA was sufficient. The findings of the study reflected the following value: $\chi 2 / \mathrm{df}=1.42$. When the value of this ratio $\mathrm{m}$ is two or below, it means that the model is a good model; and when the ratio is five or lower, it reflects a model with an acceptable goodness of fit (Şimşek, 2007). Thus, the value obtained indicated that the model was good. In addition, the value ranges of GFI (Goodness of Fit Index), AGFI (Adjusted Goodness of Fit Index), CFI (Comparative Fit Index), Normed Fit Index (NFI, Non-Normed Fit Index (NNFI), Incremental Fit Index (IFI) RMSEA (Root Mean Square Error of Approximation), and SRMR (Standardized Root Mean Square Residual), Parsimony Normed Fit Index (PNFI) and Parsimony Goodness of Fit Index (PGFI) fit indices were referenced based on the resources by Brown (2009), Hu \& Bentler (1999), Jöreskog and Sörbom (2000), Kline (2011), Raykov and Marcoulides (2006), Tabachnick and Fidell (2007), Thompson (2004), and are presented in Table 3 along with the final fir index values for the model.

Table 3: Fit statistics value ranges and values for the model analyzed in the study

\begin{tabular}{lllll}
\hline $\begin{array}{l}\text { Analyzed } \\
\text { Fit Indices }\end{array}$ & $\begin{array}{l}\text { Perfect } \\
\text { Fit Criteria }\end{array}$ & $\begin{array}{l}\text { Acceptable } \\
\text { Fit Criteria }\end{array}$ & $\begin{array}{l}\text { Obtained } \\
\text { Fit Indices }\end{array}$ & Result \\
\hline$\chi 2 /$ sd & $0 \leq \chi 2 / \mathrm{sd} \leq 2$ & $2 \leq \chi 2 / \mathrm{sd} \leq 3$ & 1.42 & Perfect fit \\
GFI & $.90 \leq \mathrm{GFI} \leq 1.00$ & $.85 \leq \mathrm{GFI} \leq 90$ & .86 & Acceptable fit \\
AGFI & $.90 \leq \mathrm{AGFI} \leq 1.00$ & $.80 \leq \mathrm{AGFI} \leq .90$ & .84 & Acceptable fit \\
CFI & $.95 \leq \mathrm{CFI} \leq 1.00$ & $.90 \leq \mathrm{CFI} \leq .95$ & .99 & Perfect fit \\
NFI & $.95 \leq \mathrm{NFI} \leq 1.00$ & $.90 \leq \mathrm{NFI} \leq .95$ & .96 & Perfect fit \\
NNFI & $.95 \leq \mathrm{NNFI} \leq 1.00$ & $.90 \leq \mathrm{NNFI} \leq .95$ & .99 & Perfect fit \\
IFI & $.95 \leq \mathrm{IFI} \leq 1.00$ & $.90 \leq \mathrm{IFI} \leq .95$ & .99 & Perfect fit \\
RMSEA & $.00 \leq \mathrm{RMSEA} \leq .05$ & $.05 \leq \mathrm{RMSEA} \leq .08$ & .037 & Perfect fit \\
SRMR & $.00 \leq \mathrm{SRMR} \leq .05$ & $.05 \leq \mathrm{SRMR} \leq .10$ & .053 & Acceptable fit \\
PNFI & $.95 \leq \mathrm{PNFI} \leq 1.00$ & $.50 \leq \mathrm{PNFI} \leq .95$ & .89 & Acceptable fit \\
PGFI & $.95 \leq \mathrm{PGFI} \leq 1.00$ & $.50 \leq \mathrm{PGFI} \leq .95$ & .73 & Acceptable fit \\
\hline \multicolumn{2}{c}{$\chi^{2}=992.24 s d=697$} & & &
\end{tabular}


As could be observed in Table 3, the model is at an acceptable level. Standardized factor loads for the final model varied between .27 and .74 . An analysis of the findings showed that t-test values varied between 5.47 and 13.93 for creativity and innovation sub-scale; between 4.76 and 13.43 for critical thinking and problem solving sub-scale; and between 3.98 and 13.93 for cooperation and communication sub-scale. Calculated $t$ values of 1.96 and higher reflects a .05 level significance, 2.58 and higher reflects a .01 level significance (Jöreskog and Sörbom, 2000; Kline, 2011). Thus, it was determined that all $\mathrm{t}$ values obtained as a result of CFA were significant at .01 significance level. Insignificant $\mathrm{t}$ values indicate that these items should be excluded from the model or it is considered as the number of participants was insufficient for the factor analysis (Byrne, 2010). Therefore, the obtained $t$ values as a result of CFA confirmed that the number of participants in the study was sufficient for factor analysis and there were no items that should be excluded from the model.

\section{Analysis of the reliability of the scale.}

The scale was finalized with 39 items as a result of the conducted analyses. Initially, item-total correlations were calculated to determine whether each item in the scale measured the factor it aimed to measure, and the efficiency of the items in differentiating individuals based on the factor they measure. Cronbach alpha internal consistency coefficient was calculated to determine the reliability of the scale. Conducted reliability analyses produced a Cronbach alpha reliability coefficient of 0.955 for the whole scale. Büyüköztürk (2007) indicated that a scale with a reliability coefficient of over 0.70 could be considered reliable. However, according to Şencan (2005), a coefficient of 0.70 or over is sufficient for scientific studies, but the scales for use in ability research should have a reliability coefficient of at least 0.85 . Evaluation of factor-based Cronbach alpha coefficients would demonstrate that Cronbach alpha coefficient was 0.958 for Factor 1; 0.943 for Factor 2; and 0.896 for Factor 3. The item-total correlations for the scale varied between .381 and .954 , thus it could be stated that the scale had a consistent structure based on the items as well. Item analysis results shows that item-total test correlations for creativity and innovation factor varied between $\mathrm{r}=$ .49 and $\mathrm{r}=.72$. item-total test correlations for critical thinking and problem solving factor varied between $\mathrm{r}=.38$ and $\mathrm{r}=.72$. For cooperation and communication factor, item-total test correlations varied between $r=.45$ and $r=.95$. Item-total correlations of .30 and higher could be used as an evidence for the validity of scale items (Nunnally and Bernstein, 1994). Item-total test correlations for the study were over $r=.30$ for each item. Thus, it could be concluded that the scale was set to measure the factors it aimed to measure.

\section{CONCLUSION AND SUGGESTIONS}

The significance of 21 st Century learning skills in education assigns a particular importance to the development of scales to measure these skills and accurate measurement of these skills. Skills that are considered within "learning and innovation" dimension of 21 st Century skills, which ought to be developed during primary education, were scrutinized in the present study and a scale that included the skills in 
this dimension was developed. As a result of the literature review of studies conducted on 21st Century skills, it was determined that there was not a full consensus on the skills that learning individuals should achieve, and there were differences in certain dimensions. Sub-dimensions of 21st Century learning and innovation skills could be classified as creativity and innovation, critical thinking and problem solving, cognitive skills or skills related to individual's self, and cooperation and communication or interpersonal skills (Kyllonen, 2012). Kang et al. (2010; 2012) developed a primary and high school level scale in cognitive, affective, and socio-cultural dimensions. It was observed that most of the studies on 21 st century skills were international studies, while most national studies were adaptations. In the present study, a new scale was developed based on P21 (2009) learning and innovation dimension and the skills accepted in ISTE NETS*S (2007). As a result of the factor analysis conducted to determine the structural validity of the scale developed in the present study, it was concluded that the final 39item scale could measure a specific structure. Results of the factor analysis demonstrated that the scale had a structure composed of three sub-dimensions. These factors were named as "creativity and innovation," "critical thinking and problem solving," and "cooperation and communication" based on the nomenclature used in the literature (P21, 2009; ISTE NETS*S, 2007). This scale is significant in the sense that all previous studies in the literature considered these skills separately, and the present scale combined those under three factors as 21 st Century learning and innovation skills scale. Similarly, the scale developed by Kang et al. $(2010 ; 2012)$ classified these skills under cognitive, affective and sociocultural sub-dimensions. Validity and reliability findings for the developed scale demonstrated that the scale had an acceptable level of reliability both as a whole and for individual factors. It was found that scale items both measured the characteristics it was aimed to measure and could differentiate between the individuals that had the measured characteristic and those who did not. Content validity of the scale was conducted with expert opinion, while structural validity tests were conducted using exploratory and confirmatory factor analyses. It was determined that standardized factor loads of the scale were at a sufficient level and $t$ values were significant. Goodness of fit indices used in the model analysis demonstrated that the fitness between the data and the model structure was acceptable.

The developed scale could be used to determine whether primary school students possessed 21st Century skills. The scale was applied at fourth grade level and validity and reliability studies were also conducted at the fourth grade level. The validity and reliability of the scale could be tested in different grade levels.

\section{REFERENCES}

Brown, J. D. (2009). Statistics Corner. Questions and answers about language testing statistics: Choosing the right number of components or factors in PCA and EFA. Shiken: JALT Testing \& Evaluation SIG Newsletter, 13(2), 19-23.

Büyüköztürk, Ş. (2007). Sosyal bilimler için veri analizi el kitabı. 7. Baskı. Ankara: Pegem A Yayıncılık. 
Byrne, B. M. (2010). Structural equation modeling with AMOS: Basic concepts. applications and programming. New York. NY: Taylor and Francis Group

Comrey, A,L, \& Lee, H.B. (1992). A first course in factor analysis (2nd edition). Hillsdale.NJ: Lawrence Erlbaum Associates.

Çam, S. ve Tümkaya. S. (2008) Kişilerarası problem çözme envanteri lise öğrencileri formu'nun geçerlik ve güvenirlik çalışması. Uluslararası İnsan Bilimleri Dergisi, 5(2).

Çelen, F. K., Çelik, A. and Seferoğlu, S. S. (2011). Türk eğitim sistemi ve pisa sonuçları. XIII. Akademik Bilişim Konferanı. İnönü Üniversitesi, Malatya. http://ab.org.tr/ab11/bildiri/ adresinden edinilmiştir.

Deborah, L. E., ( 2012) . A new generation: A new model of education in the 21 st century. Unpublished Dissertation, University of Southern California. Dede. C. (2009). Comparing Frameworks for 21st Century Skills. Retrieved from http://www.watertown.k12.ma.us/dept/ed_tech/research/pdf/ChrisDede.pdf

Demir. M. K. (2006). İlköğretim dördüncü ve beşinci slnıf ögrrencilerinin sosyal bilgiler derslerinde eleş̧irel düşünme düzeylerinin çeşitli değişkenler açısından incelenmesi. Yayınlanmamış Doktora Tezi. Gazi Üniversitesi. Ankara.

Ennis. R.H. (1991). Goals for a critical thinking curriculum, In A Costa (Ed.). Developing Minds (Vol.1). Alexandria: Virginia. ASCD

Ersoy, Y. (2008). Uluslararası Öğrenci Değerlendirme Programı (Pısa, 2006)-I: Türkiye'de Öğrencilerin Fen Okuryazarlığı. http://www.f2e2ogretmen.com/dagarcigimiz/f2e2-40.pdf adresinden_edinilmiştir.

Evcen, D. (2002). Watson-Glaser Elesstirel -Akal Yürütme Gücü Testinin (Form S)Türkçe'ye Uyarlanması: Geçerlik ve Güvenirlik Çalışması. Yayınlanmamış Yüksek Lisans Tezi. Ankara Üniversitesi Eğitim Bilimleri Enstitüsü, Ankara.

Facione, P. A., \& Facione, N. C. (1992). The California Critical Thinking Dispositions Inventory (CCTDI); and the CCTDI Test manual. Millbrae, California Academic Press.

Field, A. (2009). Discovering statistics using spss for windows. Sage: London.

$\mathrm{Ge}, \mathrm{X}$. (2001). Scaffolding students' problem-solving processes on an ill-structuredtask using question prompts and peer interactions. Unpublished dissertation, University of Pennsylvania State University.

Gültekin, M. (2007). Dünyada ve Türkiye'de İlköğretimdeki Yönelimler. Anadolu Üniversitesi Sosyal Bilimler Dergisi, 7(2), 477-502.

Heppner, P.P \& Peterson, C.H. (1982). The development and implications of a personal-problem solving inventory. Journal Of Counseling Psychology, 29, 66-75.

Hu, L. \&Bentler, P. M. (1999). Cutoff criteria for fit indexes in covariance structure analysis:conventional criteria versus new alternatives. Structural Equation Modeling, $6(1), 1-55$. 
ISTE NETS*S (2007) http://www.iste.org/docs/learning-and-leading-docs/nets-sstandards adresinden 02.03.2013 tarihinde edinilmiştir.

Jöreskog, K. \& Sörbom, D. (2000). LISREL [Computer Software]. Lincolnwood. IL: Scientific Software. Inc.

Kalaycı, Ş. (Ed.) (2005). SPSS uygulamalı çok değişkenli istatistik teknikleri. Ankara: Asil Yayın Dağıtım

Kang, M., Heo, H., Jo, I., Shin, J. \& Seo, J. (2010). Developing an Educational Performance Indicator for New Millennium Students. Journal of Research on Technology in Education, 43(2), (pp. 157-170).

Kang, M., Kim, M., Kim. B., \& You, H. (2012). Developing an instrument to measure 21 st Century Skills for Elementary student.Retrieved from, http://icome.bnu.edu.cn/sites/default/files/Full_Paper/Parallel

Keengwe, J.. Onchwari, G., \& Wachira, P. (2008). Computer technology integration and student learning: Barriers and Promise. Journal of Science Education Technology. 17, 560-565.

Kline, R. B. (2011). Principles and practice of structural equation modeling. New York: The Guilford Press.

Kyllonen, P.C. (2012). Measurement of 21st century skills within the common core state standards. Invitational Research Symposium on Technology Enhanced Assessment.

Levy, F., \& Murnane, R. (2005). How computerized work and globalization shape human skill demand, IPC Working Paper series MIT-IPC-05-006, Massachusetts Institute of Technology

Louis, R.C. (2012) . A case study exploring technology use and incorporation of 21 st century skills in elementary classrooms. Unpublished dissertation, University of Boston.

MEB. (2012). Uluslararası Matematik ve Fen Eğilimleri Araştırması 2011 Tanıtım Kitapçığı. http://egitek.meb.gov.tr/earged/arasayfa.php?g=25 adresinden edinilmiştir.

Metiri Group \& NCREL. (2003). EnGauge 21 st century skills: Literacy in the digital age. Chicago. IL: NCREL.

National Research Council. (2006). Systems for state science assessment. Washington. DC: The National Academies Press.

Nunnally, J., \& Bernstein, I. (1994). Psychometric theory. New York: McGraw-Hill.

Organization for Economic Cooperation and Development. (2005). The definition and selection of key competencies: Executive summary. Paris. France.

Özdemir, S. M. (2005). Üniversite Öğrencilerinin Eleştirel Düşünme Becerilerinin Çeşitli Değişkenler Açısından Değerlendirilmesi. Türk Ĕgitim Bilimleri Dergisi, 3(3), 297-316. 
Pallant, J. (2001). The SPSS survival manual: A step-by-step guide to data analysis using SPSS for Windows (version 10). St Leonards, NSW: Allen \& Unwin.

Partnership for 21 st Century Skills. (2006). A state leader's action guide to 21 st century skills: A new vision for education. Tucson. AZ: Partnership for 21 st Century Skills.

Partnership for 21st Century Skills (2009) Framework for 21st century learning. .Retrieved from http://www.p21.org/our-work/p21-framework.

Prensky, M. (2001). Digital Natives. Digital Immigrants .On the Horizon. 9(5). 1-6.

Raudsepp, E. (1977). 12 Vital characteristics of the Creative Supervisor. Supervision, Vol:45, 14-15.

Raykov, T. \& Marcoulides, G. A. (2006). On multilevel model reliability estimation from the perspective of structural equation modeling. Structural Equation Modeling, 13, 130-141.

Razzouk, R, \& Oroszlan, D. (2011) The Need For 21st Century Skılls Development In Our Educational System. .Retrieved from http://www.edvation.com/wpcontent/uploads/The-Need-for-21st-Century-Skills-Development-in-Our-EducationalSystem.pdf.

Rotherham, A. J..\& Willingham, D. (2009) 21st century skills: The challenges ahead. Educational Leadership, 67(1). 16-21.

Serin, O., Bulut-Serin, N. ve Saygıll, G. (2010). İlköğretim düzeyindeki çocuklar için problem çözme Envanteri'nin (çpçe) geliştirilmesi. İlköğretim Online, 9(2), 446-458.

Sharma, S. (1996). Applied multivariate techniques. USA: John Wiley \& Sons. Inc.

Shin, H.I., \& Lee, S. H. (2008). Analysis of New Millennium Learner'sbehavior. Seoul: KERIS.

Shute, V. J., \& Becker, B. J. (2010). Innovative assessment for the 21st century. New York. NY: SpringerVerlag.

Silva, E. (2009) Measuring skills for 21st-century learning. Phi Delta Kappa. 90(9). 630-634.

Stewart, V. (2010). A classroom as wide as the world. In Curriculum 21: Essential Education for a Changing World. ed. H. Hayes Jacobs. 97-114. Alexandria. VA : Association for Supervision and Curriculum Development.

Şeker, H., Deniz, S. ve Görgen, İ. (2004). Öğretmen yeterlikleri ölçeği. Milli Eğitim Dergisi, 164, 105-118

Şencan, H. (2005). Sosyal ve davranışsal ölçümlerde güvenilirlik ve geçerlilik. Ankara, Seçkin Yayınevi. 
Şimşek, Ö. F. (2007). Yapısal eşitlik modellemesine giriş: Temel ilkeler ve LISREL uygulamaları. Ankara: Ekinoks Basın Yayın Dağıtım Ltd Şti.

Tabachnick, B. G., \& Fidell, L. S. (2007). Using multivariate statistics (5th ed.). Boston: Pearson Education.

Taylan, S. (1990). Heppner'in problem çözme envanterinin uyarlama, güvenirlik ve geçerlik çalışmaları. Yayımlanmamış Yüksek Lisans Tezi, Ankara Üniversitesi Sosyal Bilimler Enstitüsü, Ankara.

Thompson, B. (2004). Exploratory and confirmatory factor analysis: Understanding concepts and applications.Washington DC: American Psychological Association

Torrance, E. P. (1990). The Torrance tests of creative thinking norms-technical manual figural (streamlined) forms $A \& B$. Bensenville. IL: Scholastic Testing Service.

Velez, A. (2012). Preparing students for the future- $21^{\text {st }}$ Century Skills. Unpublished dissertation, University of Southern California.

Watson, G., \& Glaser, E. M. (1980). Watson-Glaser critical thinking appraisal manual. Cleveland, OH: The Psychological Corporation.

Whetton, D.A.. \& Cameron, K.S. (2002). Answers to exercises taken from developing management skills. (Third edition). 176. Northwestern University.

Willingham, D. (2010). 21st Century Skills and the Teaching of History. Retrieved from, http://teachinghistory.org/issues-and-research/roundtable-response/24064

Wilmarth, S. 2010. Five socio-technology trends that change everything in learning and teaching. In Curriculum 21: Essential education for a changing world. ed. Heidi Hayes Jacobs. 80-96. Alexandria. VA : Association for Supervision and Curriculum Development.

Worthington, R. L. \& Whittaker, T. A. (2006). Scale development research a content analysis and recommendations for best practices. The Counseling Psychologist, 34(6), 806-838.

Yaman,. S. (2003). Fen bilgisi ĕgitiminde probleme dayalı öğrenmenin öğrenme ürünlerine etkisi. Yayımlanmamış Doktora Tezi, Gazi Üniversitesi, Ankara.

\section{Turkish Abstract}

21. Yüzyıl Öğrenme ve Yenilenme Becerisi Ölçeğinin Geliştirilmesi: Geçerlik ve Güvenirlik Çalışması

$\mathrm{Bu}$ çalışmanın amacı, ilkokul öğrencilerinin 21. yüzyıl öğrenme ve yenilenme becerilerini belirlemeye yönelik ölçme aracı geliştirmektir. Araştırma verileri 2014-2015 Eğitim-Öğretim Yılı Güz Dönemi'nde beş farklı ilkokuldan toplam 632 öğrenciden toplanmış, 609 öğrencinin verileri dikkate alınmıştır. Ölçek geliştirme altı aşamadan oluşmuştur. Bunlar sırayla ölçek maddelerinin oluşturulması, uzman görüşüne başvurulması, ön deneme aşaması, yapı geçerliliği tespit aşaması, güvenirlik hesaplama aşaması ve ölçeğe son şeklinin verilmesi olmak üzere altı aşamalı bir süreç 
izlenmiştir. Üç faktörden oluşan ölçeğin tamamının Cronbach alfa güvenirlilik katsayısı 0.95 olarak hesaplanmıştır. Her bir faktör için Cronbach alfa güvenirlik katsayısı $0.95,0.94$ ve 0.89 olarak hesaplanmıştır. Yapılan çalışma sonucunda, üçlü likert tipi 39 maddelik 21. yüzyıl öğrenme ve yenilenme becerisi ölçeği geliştirilmiştir. Ölçek maddelerinin 20'si yaratıcılık ve yenilenme becerisi ile ilgili, 12 'si eleştirel düşüne ve problem çözme becerisi ile ilgili, 7'si işbirliği be iletişim becerisi ile ilgilidir.

Anahtar Kelimeler: ilkokul, 21. Yüzyıl, öğrenme ve yenilenme becerileri, ölçek, geçerlik ve güvenirlik

\section{French Abstract}

Un Développement d'Échelle pour les Compétences du 21e siècle d'Étudiants d'École primaire: une Validité et une Étude de Fiabilité

L'objectif de l'étude présente est de développer un outil de mesure pour évaluer l'apprentissage du 21e siècle et les compétences d'innovation d'étudiants d'école primaire. Les données d'étude ont été rassemblées de 632 étudiants de CM1(de quatrième année) dans cinq écoles primaires différentes pendant 2014 - l'année d'universitaire de 2015 et des données obtenues de 609 étudiants de CM1(de quatrième année) ont été utilisés dans l'étude. L'échelle a été développée dans six étapes(scènes). Ceux-ci étaient; en établissant les articles d'échelle, consultation d'experts, pretest étape(scène), détermination de validité structurelle, évaluation de fiabilité et finalisation de l'échelle, respectivement. Cronbach le coefficient de fiabilité alpha pour l'échelle entière, qui a consisté en trois facteurs, a été calculé comme 0.95. 0.89. En conséquence de l'étude actuelle, un apprentissage du 21e siècle Likert-type et une échelle de compétences d'innovation avec 39 articles ont été développés. 20 articles de l'échelle ont été relatés à la créativité et les compétences d'innovation, 12 ont été relatées à la pensée critique et les compétences de résolution de problèmes et 7 ont été relatées à la coopération et des compétences de communication.

Mots Clés: école primaire, le 21e siècle, apprenant et compétences d'innovation, échelle, validité et fiabilité

\section{Arabic Abstract}

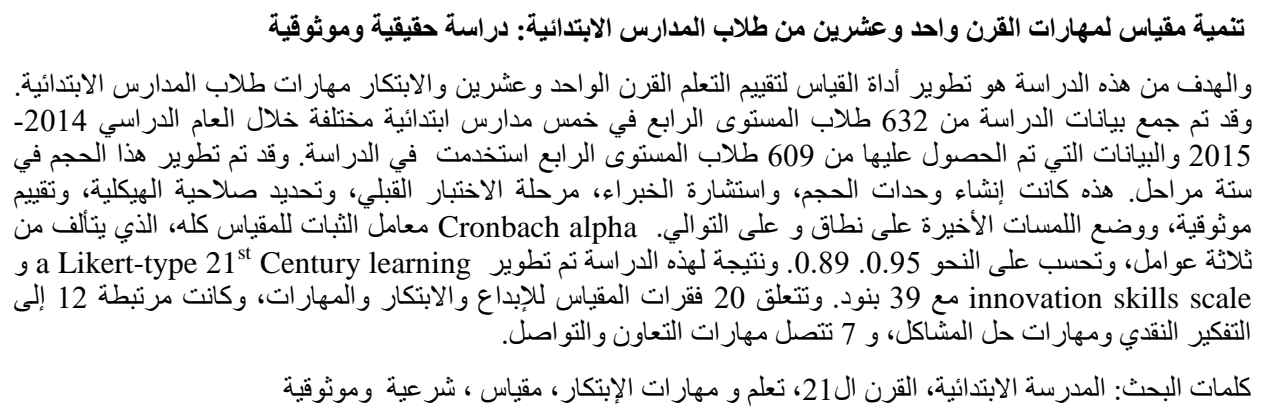

International Journal of Instruction, January $2016 \bullet$ Vol.9, No.1 